\title{
Effect of Home-Cooking Methods on Phenolic Composition and Antioxidant Activity of Sweetpotato (Ipomoea batatas (L.) Lam.) Cultivars Grown in Egypt
}

\author{
Ateea A. Bellail ${ }^{1 *}$, Omayma E. Shaltout ${ }^{1}$, Mohammed M. Youssef ${ }^{2}$, Ahmed M. A. El Gamal ${ }^{3}$ \\ ${ }^{1}$ Food Science Department, Faculty of Agriculture (Saba-Basha), Alexandria University, Alexandria, Egypt; ${ }^{2}$ Food Technology De- \\ partment, Faculty of Agriculture (El-Shatby), Alexandria University, Alexandria, Egypt; ${ }^{3}$ Plant Production Department, Faculty of \\ Agriculture (Saba-Bacha), Alexandria University, Alexandria, Egypt. \\ Email: *aaalamami@yahoo.com
}

Received January $10^{\text {th }}, 2012$; revised February $26^{\text {th }}, 2012$; accepted March $4^{\text {th }}, 2012$

\begin{abstract}
Four sweetpotato (Ipomoea batatas (L.) Lam.) cultivars grown in Alexandria, Egypt, including Monofya 6, Monofya 66, Abeeis, and Beauregard were cooked using four different home-cooking methods (boiling, baking, microwaving, and deep-frying). The antioxidant contents (total phenolics by Folin-Denis, and individual phenolic acids by HPLC) as well as the antioxidant activity determined by reducing power (RP), 2,2-diphenyl-1-picrylhydrazyl (DPPH), and 2,2'-azinobis(3-ethyl-benzothiazoline-6-sulfonic acid) (ABTS) were measured in this study. Results indicated that total phenolic contents of raw flesh tissue by Folin-Denis ranged from 0.53 to $0.87 \mathrm{mg}$ chlorogenic acid equivalent (mg ChAE)/g dry weight basis (dw). The RP ranged between 0.1 and $0.25 \mathrm{mg} \mathrm{ChAE} / \mathrm{g} \mathrm{dw}$, DPPH and ABTS radical scavenging activities varied from 1.10 to 1.72 and 0.85 to $1.51 \mu \mathrm{mol}$ trolox equivalent (TE)/g dw, respectively. Thermal processing significantly $(\mathrm{P} \leq 0.05)$ increased the total phenolic content, as well as individual phenolic acids and antioxidant capacity of all the cultivars under study. In this respect, deep-frying exhibited the highest increment among the four processing methods. The most abundant individual phenolic acids in processed flesh roots tissues were chlorogenic acid followed by 3,5-dicaffeoylquinic acid. Total phenolic contents were highly correlated with RP, DPPH, and ABTS, also the correlation between the DPPH and ABTS values were significantly high.
\end{abstract}

Keywords: Sweetpotato; Total Phenolics; Antioxidant Activity; Chlorogenic Acid; Thermal Processing; HPLC

\section{Introduction}

Sweetpotato is increasingly recognized as a health food, due to several of its nutraceutical components, which include dietary fiber, vitamin C, polyphenols, and carotenoids. The roots are considered as a highly functional, low calorie food, with anti-diabetic effects [1]. Reports indicate that these phytochemicals, especially polyphenols, have high free-radical scavenging activity, which helps to reduce the risk of chronic diseases, such as cardiovascular disease, cancer and age-related degenerative diseases [2-6].

In the middle of the last century, several attempts for the isolation and identification of phenolic compounds were performed, inspite of the limited techniques present at that time. As a matter of fact, reports on the presence of chlorogenic acid and other similar compounds in sweetpotato were found [7,8]. Accordingly, Walter et al. [9] used the high performance liquid chromatography (HPLC) to identify and quantify the individual phenolic

\footnotetext{
${ }^{*}$ Corresponding author.
}

acids in different sweetpotato cultivars. Since that time, HPLC has been used most frequently for analysis of individual phenolic acids [10-13]. Chlorogenic acid, caffeic acid, and isomers of dicaffeoylquinic acid (diCQA): 3,5-diCQA, 3,4-diCQA and 4,5-diCQA, were identified as the principal phenolic acids in sweetpotato root tissue [8,14-16]. Chlorogenic acid and 3,5-diCQA were the predominant phenolic acids in sweetpotato root tissues $[15,17,18]$.

The 2,2-diphenyl-1-picrylhydrazyl (DPPH) procedure has been used by several investigators to assay the antioxidant activity of sweetpotatoes [19-21]. There are several factors that may impact the antioxidant activity of foods; these include genetics, harvest season, geographic and environmental conditions [22], and the effect of thermal processing [23]. Meanwhile, Furuta et al. [24] reported that the purple-fleshed sweetpotato cultivar have a higher antioxidant activity and phenols than those with white, yellow or orange flesh.

High positive correlation was traced between antioxi- 
dant activity assayed by DPPH and total phenolics of sweetpotato root tissue $[17,25,26]$. This indicated that, the phenolic compounds are responsible for the antioxidant activity in the sweetpotato hydrophilic extract; therefore, the total phenolic content can be used as a useful indicator for the antioxidant activities of sweetpotatoes.

Many researchers have studied the effect of thermal processing on the content and activity of sweetpotato antioxidants. Padda and Picha [26] reported that thermal processing (Microwaving, Boiling and Baking) of the sweetpotato skin resulted in a significant loss of phenolics and antioxidant activity, but no significant loss was observed due to heat processing of cortex and pith tissue. Boiling the roots (cut into quarters) for $12 \mathrm{~min}$ increased the chlorogenic acid content and antioxidant capacity [23]. Six home-cooking techniques reduced phenolic content from $7 \%$ (baking) to $~ 40 \%$ (deep frying/boiling) [14]. Steam cooking resulted in statistically nonsignificant increases in the concentration of total phenolics and all the individual phenolic acids [17].

The objectives of the present study were: 1) to determine the antioxidant content (total phenolics, individual phenolic acids) of some sweetpotato cultivars, which have been recently grown in Saba Basha station farm located near Abeeis, Alexandria, Egypt, namely: Monofya 6 , Monofya 66 , Abeeis and Beauregard, 2) to determine the antioxidant activity of the hydrophilic extract of sweetpotatoes using two of the commonly used procedures (DPPH and ABTS), 3) to determine the effect of four home-cooking methods on the sweetpotato phenolic content and 4) to assess the relationship between the antioxidant activities of the hydrophilic extracts with the concentrations of phenolic content.

\section{Materials and Methods}

\subsection{Chemicals and Reagents}

Folin-Denis reagent, sodium carbonate, and potassium peroxodisulfate, were purchased from Fluka analytical, Germany. Methanol, acetic acid, acetonitrile, 2-propanol, formic acid, Chlorogenic acid hemihydrate 98\%, 6-hydroxy-2,5,7,8-tetramethylchromane-2-carboxylic acid (Trolox), 2,2 Diphenyl-1-picrylhydrazyl (DPPH), and 2,2'-azinobis-(3-ethylbenzothiazoline-6-sulfonic acid) diammonium salt (ABTS), from Sigma-Aldrich, Germany. Trichloroacetic acid, iron chloride, and potassium ferricyanide were purchased from BDH. Standards of chlorogenic acid, caffeic acid and three isomers (4,5dicaffeoylquinic acid (diCQA), 3,5-diCQA, and 3,4diCQA) of isochlorogenic acid (Purity $>98 \%$ ) were purchased from Chengdu Biopurify Phytochemicals Ltd., Chengdu, Sichuan, China.

\subsection{Storage of Samples}

Four sweetpotato cultivars with varying flesh color (Monofya 6, Monofya 66, Abeeis, and Beauregard), were grown in Agricultural Experiment Station, Saba Basha, Alexandria University, Alexandria, Egypt in June 2010. The roots were harvested 5 months after planting. The harvested roots were cured and stored in Cardboard box in the dark at room temperature $\left(16^{\circ} \mathrm{C}-20^{\circ} \mathrm{C}\right.$ and $\mathrm{RH}$ $60 \%-65 \%$ ) for 2 weeks, before samples were taken for analysis. The dry matter of the roots was measured within five days after harvest.

\subsection{Preparation of Different Thermally Processed Sweetpotatoes}

Seven medium size sweetpotato roots (about 350 - $400 \mathrm{~g}$ and at least $12 \mathrm{~cm}$ length) were taken randomly from each cultivar. The stored roots were thoroughly washed and brushed with tap water, wiped dry with tissue paper, and peeled gently (by removing only the skin colored layer without removing any part of the subsequent layers). Each root was cut into slices with thickness of $2 \mathrm{~cm}$. Each seven slices from different roots were collected together to form 5 section (the weight difference between these sections was $<20 \mathrm{~g}$ ). One section was randomly selected and used as a raw tissue and the remaining were randomly selected and subjected to four heat-processing methods; 1) Boiling: Where the sweetpotato slices were placed into an aluminum cook pot containing boiling water and boiled at $\left(100^{\circ} \mathrm{C}\right)$ for $14-17 \mathrm{~min}$; 2) Baking: After preheating a gas oven (conventional oven) at $180^{\circ} \mathrm{C}$, the slices were baked for $23-37 \mathrm{~min}$; 3) Microwaving: The slices were placed onto microwave plate and then cooked at $700 \mathrm{~W}$ for $6-10 \mathrm{~min}$ in a microwave oven (Moulinex, supply rating $230-50 \mathrm{~Hz}$, input power 1150 $\mathrm{W}$, output power $700 \mathrm{~W}$, frequency $2450 \mathrm{MHz}$ ) and 4) Deep fraying: The slices were fried in $100 \%$ corn oil at $180^{\circ} \mathrm{C}$ for $10-15 \mathrm{~min}$ in a deep fryer (Philips, Model: Philips Deluxe). The processing times varied according to the heat-processing method and cultivar. The determination of adequate cooking time depended on performing preliminary trail for each cultivar to avoid overcooking. All sweetpotato samples from different heat processing methods and raw tissue were homogenized with a food processor and packed in plastic plates with cover wrapped with aluminum foil and were immediately frozen at $-45^{\circ} \mathrm{C}$ and then freeze-dried at $-90^{\circ} \mathrm{C}$ for $90 \mathrm{~h}$ in a freeze-dryer (Gamma-16 LSC, Christ, Germany). Before further extraction, the lyophilized tissue was powdered with electrical mortar (Osk 13711, Ogawa Seiki, Japan) and packed in polyethylene bags and stored at $-20^{\circ} \mathrm{C}$ until analysis. 


\subsection{Tissue Extraction}

One gram of lyophilized tissue was shaked for $1 \mathrm{~h}$ in 25 $\mathrm{mL}$ of acidified methanol (7\% acetic acid in $80 \%$ methanol) and the mixture was filtered using a filter paper No. 4. The final volume was made to $25 \mathrm{~mL}$ with acidified methanol. This extract was analyzed for total phenolic content, individual phenolic acids and antioxidant activity.

\subsection{Total Phenolics}

Total phenolic content was determined using the modified Folin-Denis method [27]. The extract solution or chlorogenic acid standard $(50 \mu \mathrm{L})$ was mixed with distilled water $(1.65 \mathrm{~mL})$ and $100 \mu \mathrm{L}$ Folin-Denis reagent. After $5 \mathrm{~min}, 200 \mu \mathrm{L}$ of $1 \mathrm{~N} \mathrm{Na}_{2} \mathrm{CO}_{3}$ was added and the solution was allowed to stand for $2 \mathrm{~h}$ at room temperature. Absorbance of the resulting blue complex was measured at $750 \mathrm{~nm}$ using Aquamate Plus UV/Vis Spectrophotometer (Thermo Scientific, England). Total phenolic content was reported as $\mathrm{mg}$ of chlorogenic acid equivalents per gram dry weight sample (mg ChAE/g $\mathrm{dw})$.

\subsection{Individual Phenolic Acids}

Isolation and quantification of individual phenolic acids were obtained using a reversed-phase HPLC method described by Padda and Picha [28]. The phenolic extracts were analyzed using an Agilent 1200 Series HPLC System equipped with a UV/Vis Detector at $320 \mathrm{~nm}$. Separation was achieved on an Eclipse XBD-C18, $5 \mu \mathrm{m}, 4.6 \times$ $150 \mathrm{~mm}$ column. Phenolic acids were eluted using a mobile phase consisting of $1 \%(\mathrm{v} / \mathrm{v})$ formic acid in aqueous solution: acetonitrile: 2-propanol (70:22:8), isocratic flow rate $0.75 \mathrm{~mL} / \mathrm{min}$, injection volume $20 \mu \mathrm{L}$. Phenolic acids were identified and quantified by comparing the retention time and peak area to that of calibration curve that was constructed using the series of concentrations of known standards.

\subsection{Reducing Power Assay}

Reducing power assay was determined according to the method described by Ferreira et al. [29] An aliquot (2.5 $\mathrm{mL}$ ) of sweetpotato extract was mixed with $2.5 \mathrm{~mL}$ Phosphate buffer $(0.2 \mathrm{M}, \mathrm{pH} 6.6)$ and $2.5 \mathrm{~mL}$ of $1 \%$ potassium ferricyanide and incubated at $50^{\circ} \mathrm{C}$ for $20 \mathrm{~min}$ then rapidly cooled, mixed with $2.5 \mathrm{~mL}$ of $10 \%$ trichloroacetic acid and centrifuged at $6500 \mathrm{rpm}$ for $10 \mathrm{~min}$. The supernatant $(2.5 \mathrm{~mL})$ was mixed with distilled water $(2.5 \mathrm{~mL})$ and then freshly prepared ferric chloride $(0.5$ $\mathrm{mL}, 0.1 \%$ ) was added and allowed to stand for $10 \mathrm{~min}$. The absorbance was measured at $700 \mathrm{~nm}$ using the Aq- uamate Plus UV/Vis Spectrophotometer (Thermo Scientific, England). A blank was prepared by replacing the extract with $80 \%$ methanol. Chlorogenic acid at various concentrations was used as a standard. The reducing power activities were reported as $\mathrm{mg}$ of chlorogenic acid equivalent per gram dry sample (mg ChAE/g dw). Analysis was done in triplicate for each sample and each concentration of standard.

\subsection{DPPH Assay}

Antioxidant activity of sweetpotato extract by the DPPH assay was estimated according to the procedure described by Brand-Williams et al. [30] with slight modifications. A sample or a standard $(100 \mu \mathrm{L})$ was added to $1.9 \mathrm{~mL}$ of DPPH solution in methanol $(60 \mu \mathrm{M})$. After $2 \mathrm{~h}$ incubation, the absorbance at $517 \mathrm{~nm}$ was measured in a $1 \mathrm{~cm}$ cell using Aquamate Plus UV/Vis Spectrophotometer (Thermo Scientific, England). Methanol (80\%) was used as a blank, and the sweetpotato extract was replaced with $80 \%$ methanol in the control. Trolox $(0-400 \mu \mathrm{M})$ was used as a standard. Analysis was done in triplicate for each sample and each concentration of standard. The antioxidant was expressed in terms of $\mu$ mole Trolox equivalents per gram dry weight ( $\mu \mathrm{mol} \mathrm{TE} / \mathrm{g} \mathrm{dw})$.

\subsection{ABTS Assay}

The ABTS radical scavenging activity was carried out by the method of Miller and Rice-Evans [31], in which the ABTS solution was prepared by mixing $8 \mathrm{mM}$ of ABTS with $3 \mathrm{mM}$ of potassium persulphate in $25 \mathrm{~mL}$ of distilled water. The solution was held at room temperature in the dark for 16 hours before use. The $\mathrm{ABTS}^{\circ+}$ solution was diluted with $80 \%$ methanol in order to obtain an absorbance between $0.8-0.9$ at $734 \mathrm{~nm}$. Antioxidant or standard solutions, $100 \mu \mathrm{L}$, were mixed with $1.9 \mathrm{~mL}$ of diluted $\mathrm{ABTS}^{\circ+}$ solution. The absorbance at $734 \mathrm{~nm}$ was read after 7 min using the Aquamate Plus UV/Vis Spectrophotometer (Thermo Scientific, England). Methanol $(80 \%)$ was used as a blank, and the sweetpotato extract was replaced with $80 \%$ methanol in the control. Trolox with concentrations from 0 to $250 \mu \mathrm{M}$ were used as standards. The free radical scavenging activity was expressed as $\mu$ mole Trolox equivalents per gram dry weight $(\mu \mathrm{mol} \mathrm{TE} / \mathrm{g} \mathrm{dw})$. All determinations were performed in triplicate.

\subsection{Statistical Analysis}

The experiment was conducted with 3 replicates in a randomized complete design. Values were expressed as means \pm standard error, and the differences between groups were evaluated using one-way analysis of vari- 
ance $(A N O V A)$ at $(P \leq 0.05)$. Means were separated using Duncan's multiple range test. Pearson correlation coefficients were calculated between the results of total phenolics and different antioxidant assays, and between different antioxidant assays. These statistical analysis were carried out using Microsoft Excel 2007.

\section{Results and Discussion}

\subsection{Total Phenolics}

The total phenolics (by Folin-Denis) of the sweetpotato flesh root tissues with different home-cooking methods are shown in Table 1. The total phenolic content of the raw sweetpotato flesh tissues ranged from $0.53 \mathrm{mg}$ chlorogenic acid equivalent (ChAE)/g dw for (Monofya 6) to $0.87 \mathrm{mg} \mathrm{ChAE} / \mathrm{g} \mathrm{dw}$ for (Beauregard). For each cultivar of sweetpotato, the phenolic contents of the processed samples were higher than that of raw sample, and the result indicates that all home processing methods resulted in a significant increase $(\mathrm{P} \leq 0.05)$ in phenolic content of the flesh tissues. The increasing rate was in the following order: deep-frying $>$ baking $>$ boiling $>$ microwaving. Obviously, deep-frying showed the highest increase in total phenolics for all cultivars, while microwave cooking exhibited the least in this respect. Boiling and microwaving showed the highest total phenolics with Beauregard cultivar (2.8 and 2.6 times, respectively), while baking and deep-frying had the highest phenolics content with Monofya 6 cultivar (5.3 and 6.5 times, respectively) as compared to the raw samples. However, the increasing rate seems to be cultivar dependent.

Boiling of the plugged roots from the central part with $5 \mathrm{~cm}$ long for $10 \mathrm{~min}$, had a lesser effect on total phenolic content measured by Folin-Ciocalteu and on antioxidative activity by DPPH as described by Jung et al. [14].

Padda and Picha [26] reported that the thermal processing of the sweetpotato skin resulted in a significant loss of total phenolic content by $42 \%$ after microwaving, $55 \%$ after conventional oven baking, and $37 \%$ after boil- ing. Differences in total phenolic content among the aforementioned three processing methods were not significant, and no significant losses of total phenolic content could be traced due to heat processing of cortex and pith tissue. Rautenbach et al. [23] observed an increase in the total phenolic content in four sweetpotato cultivars after thermal processing (boiling for $20 \mathrm{~min}$ ), and the increases varied between $21.1 \%$ and $79.1 \%$.

Heat processing could cause the damage of cell structures of sweetpotato roots and resulted in more easy extraction of antioxidant components from the root itself or those from the peel diffusing to the root [25]. The present research results indicate that because of peeling sweetpotato samples, cell structures damage took place which resulted in increasing the efficiency of extraction.

\subsection{Individual Phenolic Acids by HPLC}

The effect of different home-cooking methods on the individual phenolic acids content in sweetpotato flesh roots tissues are summarized in Table 2. Four major peaks were separated and identified as chlorogenic acid (peak 1), 3,4-diCQA (peak 2), 3,5-diCQA (peak 3), and 4,5-diCQA (peak 4). The elution order of these compounds was not in accordance with that of sweetpotato pith root tissues from Beauregard cultivar reported by Padda and Picha [28]. Moreover, none of the flesh root tissues for all cultivars analyzed showed a detectable peak for caffeic acid. The 3,5-diCQA was the most abundant individual phenolic acid present in raw sweetpotato flesh tissues. Whereas, in all processed samples, chlorogenic acid had the highest values followed by 3,5-diCQA, 4,5-diCQA, and 3,4-diCQA had the lowest value. The chlorogenic acid contents were 1.1, 1.7, 2.8, and $3.0 \mathrm{mg} / 100 \mathrm{~g} \mathrm{dw}$ for Monofya 66, Monofya 6, Beauregard, and Abeeis, respectively. The 3,5-diCQA values were $1.3,2.7,3.5$, and $4.6 \mathrm{mg} \mathrm{ChAE} / 100 \mathrm{~g} \mathrm{dw}$ for Monofya 66, Monofya 6, Beauregard, and Abeeis, respectively. Monofya 66 had the lowest concentration of

Table 1. Effect of different processing methods on total phenolics in four cultivars of sweetpotato.

\begin{tabular}{ccccc}
\hline \multirow{2}{*}{ Treatment } & \multicolumn{3}{c}{ Cultivar } \\
\cline { 2 - 5 } & Monofya 6 & Monofya 66 & Abeeis & Beauregard \\
\hline Raw & ${ }^{\mathrm{C}} 0.53^{\mathrm{e}} \pm 0.009$ & ${ }^{\mathrm{B}} 0.63^{\mathrm{e}} \pm 0.012$ & ${ }^{\mathrm{A}} 0.83^{\mathrm{e}} \pm 0.016$ & ${ }^{\mathrm{A}} 0.87^{\mathrm{e}} \pm 0.009$ \\
Boiled & $1.50^{\mathrm{c}} \pm 0.016$ & $1.18^{\mathrm{c}} \pm 0.018$ & $1.26^{\mathrm{c}} \pm 0.025$ & $2.47^{\mathrm{c}} \pm 0.028$ \\
Baked & $2.81^{\mathrm{b}} \pm 0.024$ & $2.88^{\mathrm{b}} \pm 0.019$ & $3.09^{\mathrm{b}} \pm 0.040$ & $3.06^{\mathrm{b}} \pm 0.065$ \\
Microwaved & $1.23^{\mathrm{d}} \pm 0.009$ & $1.03^{\mathrm{d}} \pm 0.01$ & $1.15^{\mathrm{d}} \pm 0.033$ & $2.26^{\mathrm{d}} \pm 0.040$ \\
Deep fried & $3.43^{\mathrm{a}} \pm 0.030$ & $3.14^{\mathrm{a}} \pm 0.02$ & $3.35^{\mathrm{a}} \pm 0.010$ & $3.67^{\mathrm{a}} \pm 0.072$ \\
\hline
\end{tabular}

${ }^{\text {a-e }}$ Means within a column with different letter are significantly different $(\mathrm{P} \leq 0.05) .{ }^{\mathrm{A}-\mathrm{C}}$ Means within a raw with different letter are significantly different $(\mathrm{P} \leq$ $0.05)$. Means (mg chlorogenic acid equivalent/g dry weight) $\pm \mathrm{SE}$ of triplicate. 
Table 2. Individual phenolic acids content in raw and processed sweetpotato flesh root tissues.

\begin{tabular}{|c|c|c|c|c|c|c|}
\hline \multirow{2}{*}{ Cultivar } & \multirow{2}{*}{ Treatment } & \multicolumn{5}{|c|}{ Individual phenolic (mg/100g dw) } \\
\hline & & ChA & 3,4-diCQA & 3,5-diCQA & 4,5-diCQA & Total phenolic \\
\hline \multicolumn{7}{|l|}{ Monofya 6} \\
\hline & Raw & ${ }^{\mathrm{BC}} 1.7^{\mathrm{e}} \pm 0.04$ & ${ }^{\mathrm{A}} 1.0^{\mathrm{e}} \pm 0.05$ & $\mathrm{AB}_{2 .} .7^{\mathrm{C}} \pm 0.71$ & ${ }^{\mathrm{A}} 2.1^{\mathrm{e}} \pm 0.02$ & ${ }^{\mathrm{A}} 8.0^{\mathrm{e}} \pm 0.57$ \\
\hline & $\mathrm{BL}$ & $13.7^{\mathrm{c}} \pm 0.41$ & $3.6^{\mathrm{c}} \pm 0.05$ & $8.5^{\mathrm{b}} \pm 0.24$ & $4.5^{\mathrm{c}} \pm 0.06$ & $30.3^{\mathrm{c}} \pm 0.76$ \\
\hline & BK & $22.0^{\mathrm{b}} \pm 0.25$ & $3.9^{b} \pm 0.05$ & $7.8^{\mathrm{b}} \pm 0.04$ & $4.8^{\mathrm{b}} \pm 0.04$ & $38.5^{\mathrm{b}} \pm 0.38$ \\
\hline & MW & $10.1^{\mathrm{d}} \pm 0.96$ & $2.3^{\mathrm{d}} \pm 0.05$ & $9.1^{b} \pm 0.46$ & $3.2^{\mathrm{d}} \pm 0.11$ & $24.6^{\mathrm{d}} \pm 0.34$ \\
\hline & DF & $30.6^{\mathrm{a}} \pm 0.54$ & $5.6^{\mathrm{a}} \pm 0.00$ & $11.0^{\mathrm{a}} \pm 0.11$ & $7.1^{\mathrm{a}} \pm 0.05$ & $54.3^{\mathrm{a}} \pm 0.71$ \\
\hline \multicolumn{7}{|c|}{ Monofya 66} \\
\hline & Raw & ${ }^{\mathrm{C}} 1.1^{\mathrm{d}} \pm 0.14$ & nd & ${ }^{\mathrm{B}} 1.3^{\mathrm{b}} \pm 0.01$ & ${ }^{\mathrm{B}} 1.5^{\mathrm{c}} \pm 0.03$ & ${ }^{\mathrm{B}} 3.8^{\mathrm{d}} \pm 0.12$ \\
\hline & $\mathrm{BL}$ & $9.3^{c} \pm 0.22$ & $2.5^{\mathrm{c}} \pm 0.19$ & $4.6^{\mathrm{a}} \pm 0.07$ & $3.5^{\mathrm{b}} \pm 0.28$ & $20.0^{c} \pm 0.33$ \\
\hline & BK & $20.8^{\mathrm{b}} \pm 0.19$ & $3.4^{\mathrm{b}} \pm 0.32$ & $5.1^{\mathrm{a}} \pm 0.25$ & $4.4^{\mathrm{ab}} \pm 0.53$ & $33.7^{\mathrm{b}} \pm 1.3$ \\
\hline & MW & $6.6^{\mathrm{c}} \pm 0.78$ & $1.2^{\mathrm{d}} \pm 0.09$ & $5.8^{\mathrm{a}} \pm 1.3$ & $2.0^{\mathrm{c}} \pm 0.08$ & $15.7^{\mathrm{c}} \pm 2.1$ \\
\hline & DF & $25.6^{\mathrm{a}} \pm 1.4$ & $4.4^{\mathrm{a}} \pm 0.01$ & $7.2^{\mathrm{a}} \pm 0.44$ & $5.5^{\mathrm{a}} \pm 0.02$ & $42.7^{\mathrm{a}} \pm 1.9$ \\
\hline \multicolumn{7}{|l|}{ Abeeis } \\
\hline & Raw & ${ }^{\mathrm{A}} 3.0^{\mathrm{d}} \pm 0.36$ & nd & ${ }^{\mathrm{A}} 4.6^{\mathrm{C}} \pm 0.22$ & nd & ${ }^{A} 7.6^{d} \pm 0.57$ \\
\hline & $\mathrm{BL}$ & $7.7^{\mathrm{c}} \pm 0.42$ & $3.2^{b} \pm 0.17$ & $4.8^{\mathrm{bc}} \pm 0.27$ & $3.9^{\mathrm{a}} \pm 0.03$ & $19.6^{c} \pm 0.83$ \\
\hline & BK & $24.7^{b} \pm 0.16$ & $4.7^{\mathrm{a}} \pm 0.35$ & $7.4^{\mathrm{ab}} \pm 0.22$ & $5.3^{\mathrm{a}} \pm 0.80$ & $42.1^{\mathrm{b}} \pm 1.2$ \\
\hline & MW & $7.8^{\mathrm{c}} \pm 0.38$ & $2.1^{\mathrm{c}} \pm 0.12$ & $9.6^{\mathrm{a}} \pm 1.2$ & $2.6^{\mathrm{a}} \pm 0.12$ & $22.2^{\mathrm{c}} \pm 0.83$ \\
\hline & $\mathrm{DF}$ & $28.9^{\mathrm{a}} \pm 0.41$ & $4.7^{\mathrm{a}} \pm 0.14$ & $7.5^{\mathrm{a}} \pm 0.04$ & $5.8^{\mathrm{a}} \pm 0.68$ & $46.9^{\mathrm{a}} \pm 0.44$ \\
\hline \multicolumn{7}{|c|}{ Beauregard } \\
\hline & Raw & ${ }^{\mathrm{AB}} 2.8^{\mathrm{d}} \pm 0.30$ & ${ }^{\mathrm{A}} 1.1^{\mathrm{e}} \pm 0.01$ & ${ }^{\mathrm{A}} 3.5^{\mathrm{c}} \pm 0.44$ & nd & ${ }^{\mathrm{A}} 7.4^{\mathrm{C}} \pm 0.73$ \\
\hline & $\mathrm{BL}$ & $22.1^{\mathrm{bc}} \pm 1.1$ & $8.3^{b} \pm 0.07$ & $16.5^{\mathrm{bc}} \pm 0.58$ & $10.1^{b} \pm 0.35$ & $57.1^{\mathrm{b}} \pm 1.2$ \\
\hline & BK & $26.9^{b} \pm 1.1$ & $7.4^{\mathrm{c}} \pm 0.20$ & $18.8^{\mathrm{b}} \pm 0.41$ & $8.3^{b} \pm 0.75$ & $61.5^{\mathrm{b}} \pm 0.59$ \\
\hline & MW & $21.9^{c} \pm 1.1$ & $6.6^{\mathrm{d}} \pm 0.22$ & $33.4^{\mathrm{a}} \pm 6.5$ & $5.7^{\mathrm{c}} \pm 0.33$ & $67.5^{\mathrm{ab}} \pm 5.3$ \\
\hline & DF & $34.2^{\mathrm{a}} \pm 1.4$ & $9.8^{\mathrm{a}} \pm 0.16$ & $19.8^{\mathrm{b}} \pm 0.70$ & $12.5^{\mathrm{a}} \pm 0.39$ & $76.4^{\mathrm{a}} \pm 1.5$ \\
\hline
\end{tabular}

${ }^{\mathrm{a} e}$ Means in a column of the same cultivar with different letter are significantly different $(\mathrm{P} \leq 0.05)$. ${ }^{\mathrm{A}-\mathrm{C}}$ Means in a column of the same treatment with different letter are significantly different $(\mathrm{P} \leq 0.05)$. ChA: chlorogenic acid; diCQA: dicaffeoylquinic acid; BL: boiled; BK: baked; MW: microwaved; DF: deep-fried; nd: not detected. Means \pm SE of duplicate.

both acids and was significantly different from Abeeis and Beauregard cultivars. Results indicated that the processing methods resulted in significant increase $(\mathrm{P} \leq$ $0.05)$ in individual phenolic acids of the sweetpotato flesh root tissues. Deep-frying process exhibited the highest increase of individual phenolic acids among all other processing methods followed by baking, boiling or microwaving.

Padda and Picha [15] reported that the chlorogenic acid content of 14 sweetpotato cultivars with different flesh colors ranged between 2.59 and $42.24 \mathrm{mg} / 100 \mathrm{~g} \mathrm{dw}$, the caffeic acid was present in the lowest concentration among all the individual phenolic acids identified except in the skin tissue. They didn't observe any significant effect on the chlorogenic acid content in the cortex or pith tissue. The chlorogenic acid content in 4 sweetpotato cultivars determined by Rautenbach et al. [23] ranged between 13.87 to $28.06 \mathrm{mg} / 100 \mathrm{~g} \mathrm{dw}$. Our observations are not consistent with Jung et al. [14] who reported reductions in total caffeoylquinic acids $(\mathrm{P} \leq 0.005)$, and observed significant differences $(\mathrm{P} \leq 0.001)$ among the treatments, with losses occurring in the following order: 
boiling $>$ deep frying $>$ sautéing or steaming $>$ microwaving or oven baking. The boiling process exhibited the highest losses in the most abundant phenolic acids (ChA and 3,5-diCQA), followed by samples that were deepfried.

\subsection{Antioxidant Activity}

\subsubsection{Reducing Power Assay}

The reducing power activities of raw flesh tissues ranged from 0.1 to $0.25 \mathrm{mg} \mathrm{ChAE} / \mathrm{g} \mathrm{dw}$ (Table 3), and the differences between Abeeis and Beauregard were not significant $(P \leq 0.05)$. All cooking methods showed significant increase in reducing power values. Similar to the total phenolics; the deep-frying process had the highest effect. The results indicate that all methods had shown the highest effect with (Monofya 6) cultivar. Furthermore, the differences were significant $(\mathrm{P} \leq 0.05)$ between these methods on the same cultivar. Our results are consistent with Huang et al. [25] who indicated an increase in the reducing power of six sweetpotato genotypes as a result of steaming and kneading treatments as compared with their raw counterpart.

\subsubsection{DPPH Assay}

The DPPH values for raw and processed flesh root tissue samples are shown in Table 4. For raw samples, Abeeis cultivar exhibited the highest antioxidant activity with $1.83 \mu \mathrm{mol} \mathrm{TE} / \mathrm{g} \mathrm{dw}$, while the lowest antioxidant activity was represented by Monofya 6 with $1.10 \mu \mathrm{mol} \mathrm{TE} / \mathrm{g} \mathrm{dw}$, meanwhile, the difference between Monofya 6 and Monofya 66 were not significant. All home-cooking processes resulted in a significant increase in DPPH values for all cultivars, where a significant difference $(\mathrm{P} \leq 0.05)$ was observed among all methods. The scavenging activities of sweetpotato flesh root tissues for different processing methods were in the following order: deep-frying $>$ baking $>$ boiling $>$ microwaving $>$ raw. As in total phenolic results, the boiling and microwaving showed the highest effect (3.7 and 3.5 times, respectively) with Beauregard cultivar, while the baking and deep-frying had the highest effect (4.5 and 5.8 times, respectively) with Monofya 6 cultivar. Among 6 genotypes of sweetpotato from Taiwan, the purple-fleshed sweetpotato genotypes showed superior in the scavenging DPPH radical effects as compared to other genotypes, and the DPPH values of sweet potato root tissues with different treatments were in the order of: kneaded $>$ steamed $>$ raw [25]. Steed and Truong [32] could not observe a significant difference in DPPH values among raw $(75.5 \mu \mathrm{mol}$ $\mathrm{TE} / \mathrm{g} \mathrm{fw}$ ) and steamed samples for $30 \mathrm{~min}$ at $100^{\circ} \mathrm{C}$

Table 3. Effect of different processing methods on reducing power in four cultivars of sweetpotato.

\begin{tabular}{|c|c|c|c|c|}
\hline \multirow{2}{*}{ Treatment } & \multicolumn{4}{|c|}{ Cultivar } \\
\hline & Monofya 6 & Monofya 66 & Abeeis & Beauregard \\
\hline Raw & ${ }^{\mathrm{C}} 0.10^{\mathrm{e}} \pm 0.009$ & ${ }^{\mathrm{D}} 0.14^{\mathrm{e}} \pm 0.005$ & ${ }^{\mathrm{A}} 0.22^{\mathrm{d}} \pm 0.010$ & ${ }^{\mathrm{A}} 0.25^{\mathrm{e}} \pm 0.012$ \\
\hline Boiled & $0.70^{c} \pm 0.008$ & $0.50^{c} \pm 0.017$ & $0.65^{\mathrm{c}} \pm 0.025$ & $1.25^{\mathrm{c}} \pm 0.010$ \\
\hline Baked & $1.15^{\mathrm{b}} \pm 0.013$ & $1.29^{\mathrm{b}} \pm 0.013$ & $1.42^{\mathrm{b}} \pm 0.014$ & $1.42^{\mathrm{b}} \pm 0.018$ \\
\hline Microwaved & $0.58^{\mathrm{d}} \pm 0.012$ & $0.39^{\mathrm{d}} \pm 0.019$ & $0.56^{\mathrm{c}} \pm 0.012$ & $1.15^{\mathrm{d}} \pm 0.010$ \\
\hline Deep fried & $1.59^{\mathrm{a}} \pm 0.014$ & $1.51^{\mathrm{a}} \pm 0.018$ & $1.68^{\mathrm{a}} \pm 0.010$ & $1.65^{\mathrm{a}} \pm 0.039$ \\
\hline
\end{tabular}

${ }^{\mathrm{a}-\mathrm{e}}$ Means within a column with different letter are significantly different $(\mathrm{P} \leq 0.05) .{ }^{\mathrm{A}-\mathrm{D}}$ Means within a raw with different letter are significantly different $(\mathrm{P} \leq$ 0.05 ). Means (mg chlorogenic acid equivalent $/ \mathrm{g}$ dry weight) $\pm \mathrm{SE}$ of triplicate.

Table 4. Effect of different processing methods on DPPH in four cultivars of sweetpotato.

\begin{tabular}{ccccc}
\hline \multirow{2}{*}{ Treatment } & \multicolumn{3}{c}{ Cultivar } \\
\cline { 2 - 5 } & Monofya 6 & Monofya 66 & Abeeis & Beauregard \\
\hline Raw & ${ }^{\mathrm{C}} 1.10^{\mathrm{e}} \pm 0.008$ & ${ }^{\mathrm{C}} 1.16^{\mathrm{e}} \pm 0.030$ & ${ }^{\mathrm{A}} 1.83^{\mathrm{e}} \pm 0.028$ & ${ }^{\mathrm{B}} 1.72^{\mathrm{e}} \pm 0.021$ \\
Boiled & $3.78^{\mathrm{c}} \pm 0.034$ & $3.23^{\mathrm{c}} \pm 0.021$ & $3.35^{\mathrm{c}} \pm 0.008$ & $6.29^{\mathrm{c}} \pm 0.036$ \\
Baked & $5.00^{\mathrm{b}} \pm 0.033$ & $4.29^{\mathrm{b}} \pm 0.031$ & $5.61^{\mathrm{b}} \pm 0.016$ & $6.88^{\mathrm{b}} \pm 0.028$ \\
Microwaved & $2.79^{\mathrm{d}} \pm 0.008$ & $2.55^{\mathrm{d}} \pm 0.020$ & $2.94^{\mathrm{d}} \pm 0.045$ & $5.95^{\mathrm{d}} \pm 0.012$ \\
Deep fried & $6.34^{\mathrm{a}} \pm 0.018$ & $5.06^{\mathrm{a}} \pm 0.044$ & $6.42^{\mathrm{a}} \pm 0.023$ & $8.07^{\mathrm{a}} \pm 0.031$ \\
\hline
\end{tabular}

${ }^{\mathrm{a}-\mathrm{e}}$ Means within a column with different letter are significantly different $(\mathrm{P} \leq 0.05) .{ }^{\mathrm{A}-\mathrm{C}}$ Means within a raw with different letter are significantly different $(\mathrm{P} \leq$ $0.05)$. Means ( $\mu$ mol Trolox equivalents/g dry weight $) \pm \mathrm{SE}$ of triplicate. 
(77.1 $\mu \mathrm{mol} \mathrm{TE} / \mathrm{g} \mathrm{fw})$ for flesh root of purple skin and flesh sweetpotato cultivar.

\subsubsection{ABTS Assay}

The ABTS values of the raw flesh tissues ranged between 0.85 (Monofya 6) and $1.51 \mu \mathrm{mol} \mathrm{TE} / \mathrm{g} \mathrm{dw}$ (Abeeis) as shown in Table 5. All raw samples were significantly different $(\mathrm{P} \leq 0.05)$. The effects of processing methods on the antioxidant activity determined by ABTS are different depending on the cultivar. However, the rank order among the cultivar was similar to the DPPH results. The boiling and microwaving showed the highest rate of increase with Beauregard cultivar (4.5 and 4.0 times, respectively), while the baking and deep-frying showed the highest effect on Monofya 6 (6.6 and 8.6 times, respectively). The effect of processing methods on increasing the antioxidant activity was in the following order: boiling: Beauregard $>$ Monofya $6>$ Monofya $66>$ Abeeis, baking: Monofya $6>$ Monofya $66>$ Beauregard $>$ Abeeis, microwaving: Beauregard $>$ Monofya $6>$ Monofya $66>$ Abeeis, and deep-frying: Monofya $6>$ Monofya 66 $>$ Beauregard $>$ Abeeis. The Abeeis cultivar exhibited the lowest effect by thermal processing among the cultivars. Statistical analysis showed that the ABTS values of the raw and processed samples of flesh tissues were statistically different $(\mathrm{P} \leq 0.05)$, and the same thing among the different home processing methods. The thermal processing increased the ABTS values more than the DPPH. The antioxidant activity assay of sweetpotato cultivars with different flesh color determined by Teow et al. [33] showed that the purple sweetpotato cultivars had the highest ABTS, while the white and yellow fleshed had the lowest activities, and most of the orange fleshed samples were in a middle range. Our observations are consistent with Rautenbach et al. [23] who reported an increase in the ABTS values (ranged from $6.1 \%$ to $42.9 \%$ ) of four sweetpotato cultivars that were boiled for $12 \mathrm{~min}$. In the present research, the results indicate that there is an agreement between the results of total phenolics with that of antioxidant activity, and that the pattern of change in the total phenolics results due to thermal processing was parallel to that of the antioxidant activity.

\subsection{Correlations}

As shown in Figures 1-4, total phenolic contents (Folin-Dins) were highly significantly correlated with the reducing power values $(\mathrm{r}=0.988, \mathrm{P} \leq 0.0001)$, DPPH activities $(\mathrm{r}=0.926, \mathrm{P} \leq 0.0001)$, ABTS activities $(\mathrm{r}=$ $0.981, \mathrm{P} \leq 0.0001)$, and total phenolic content determined by HPLC $(r=0.867, P \leq 0.0001)$. The correlation between the DPPH and ABTS values were also highly significant $(r=0.924, P \leq 0.0001)$ as shown in Figure 5 . The results suggested that the two methods had similar predictive capacity for antioxidant activities of sweetpotato. Teow et al. [33] reported a high correlation between total phenolics and DPPH $(\mathrm{r}=0.932, \mathrm{P} \leq 0.0001)$ and a moderate correlation with ABTS $(\mathrm{r}=0.83, \mathrm{P} \leq 0.0001)$, and the correlation between the ABTS and DPPH values were also highly significant $(r=0.907, \mathrm{P} \leq 0.0001)$. It was reported that correlation $(\mathrm{r}=0.98)$ existed between total phenolic content and antioxidant capacity determined by DPPH in sweetpotato root tissue [26]. The total phenolics (sum of HPLC peaks) were highly correlated with Folin-Ciocalteu $(r=0.985)$ and DPPH $(r=0.959$, P $\leq$ 0.001) [14]. Through the growing number of researches, which frequently refer as to high and strong correlation between total phenolics and antioxidant activity, we can benefit from this correlation to monitor changes in the antioxidant activity as a result of handling, storage and thermal processing by estimating the total phenolic assay, which is simple and cheap technique as compared to the antioxidant activity assays.

\section{Conclusion}

The present study showed that home processing methods elevated the phenolic content and antioxidant activity of

Table 5. Effect of different processing methods on ABTS in four cultivars of sweetpotato.

\begin{tabular}{ccccc}
\hline \multirow{2}{*}{ Treatment } & \multicolumn{3}{c}{ Cultivar } \\
\cline { 2 - 5 } & Monofya 6 & Monofya66 & Abeeis & Beauregard \\
\hline Raw & ${ }^{\mathrm{D}} 0.85^{\mathrm{e}} \pm 0.006$ & ${ }^{\mathrm{C}} 0.97^{\mathrm{e}} \pm 0.018$ & ${ }^{\mathrm{A}} 1.51^{\mathrm{e}} \pm 0.041$ & ${ }^{\mathrm{B}} 1.25^{\mathrm{e}} \pm 0.012$ \\
Boiled & $3.67^{\mathrm{c}} \pm 0.021$ & $3.10^{\mathrm{c}} \pm 0.012$ & $3.08^{\mathrm{c}} \pm 0.009$ & $5.66^{\mathrm{c}} \pm 0.016$ \\
Baked & $5.60^{\mathrm{b}} \pm 0.020$ & $6.22^{\mathrm{b}} \pm 0.025$ & $6.62^{\mathrm{b}} \pm 0.013$ & $6.16^{\mathrm{b}} \pm 0.012$ \\
Microwaved & $2.73^{\mathrm{d}} \pm 0.019$ & $2.34^{\mathrm{d}} \pm 0.021$ & $2.55^{\mathrm{d}} \pm 0.010$ & $5.02^{\mathrm{d}} \pm 0.024$ \\
Deep fried & $7.27^{\mathrm{a}} \pm 0.020$ & $7.17^{\mathrm{a}} \pm 0.020$ & $8.99^{\mathrm{a}} \pm 0.042$ & $8.42^{\mathrm{a}} \pm 0.007$ \\
\hline
\end{tabular}

${ }^{\mathrm{a}-\mathrm{e}}$ Means within a column with different letter are significantly different $(\mathrm{P} \leq 0.05)$. ${ }^{\mathrm{A}-\mathrm{D}}$ Means within a raw with different letter are significantly different $(\mathrm{P} \leq$ 0.05 ). Means ( $\mu$ mol Trolox equivalents/g dry weight $) \pm \mathrm{SE}$ of triplicate. 


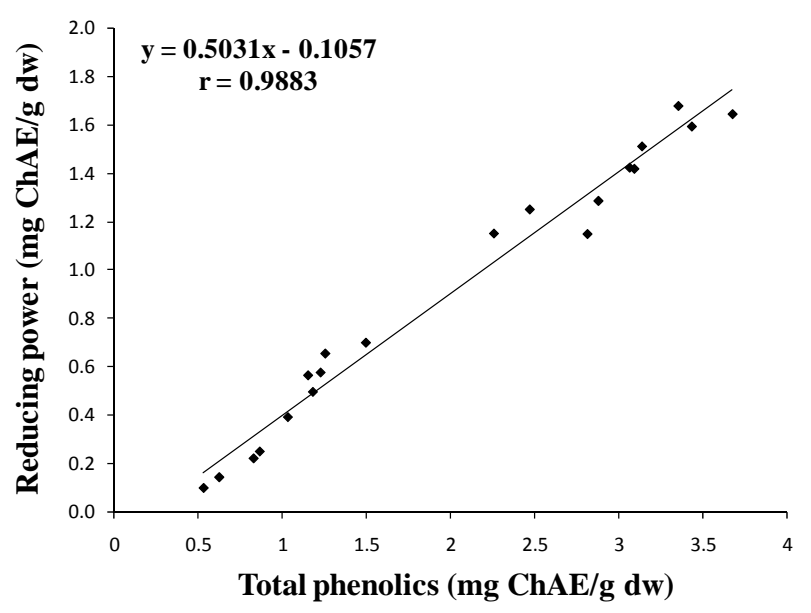

Figure 1. Correlation between total phenolics content and reducing power.

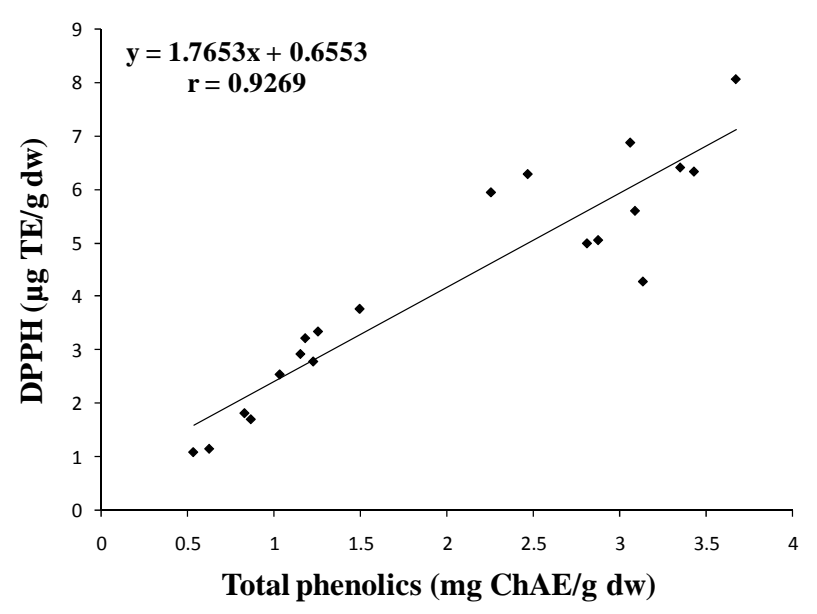

Figure 2. Correlation between total phenolics content and DPPH values.

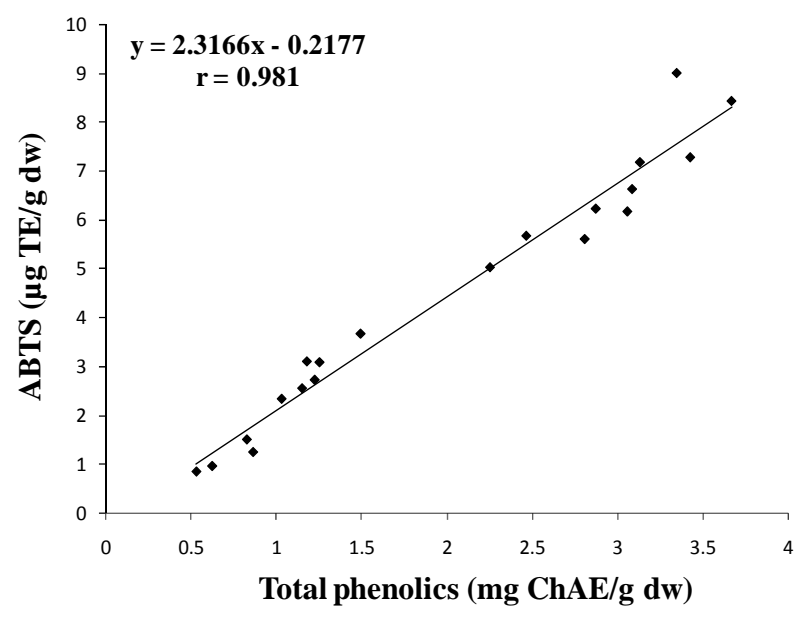

Figure 3. Correlation between total phenolics content and ABTS values.

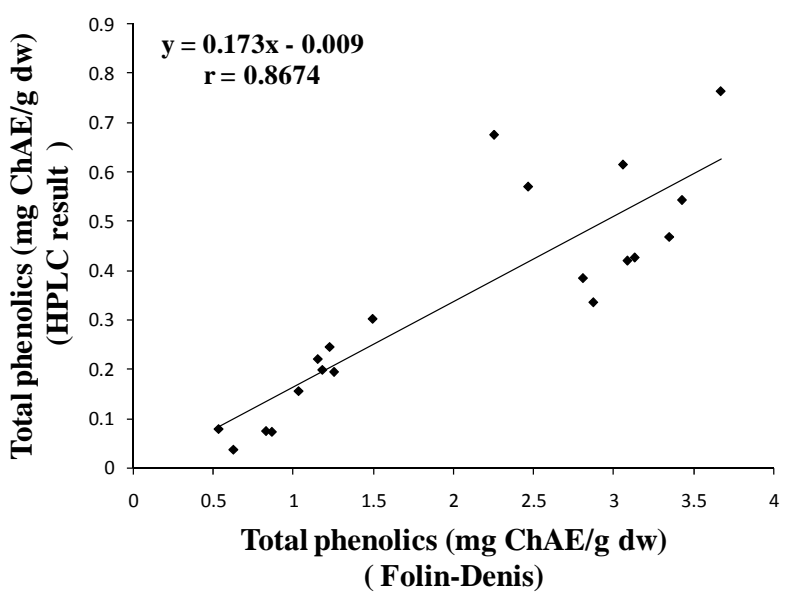

Figure 4. Correlation between total phenolics (HPLC) and total phenolics (Folin-Denis).

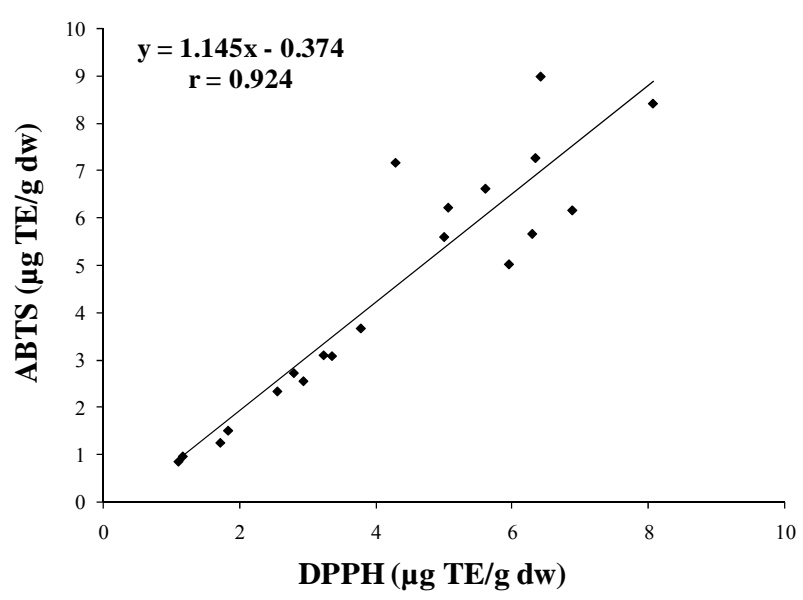

Figure 5. Correlation between DPPH and ABTS.

all sweetpotato cultivars. The deep-frying process exhibited the highest increase in phenolic content and antioxidant capacity. Chlorogenic acid and 3,5-diCQA were the most abundant individual phenolic acids in sweetpotato flesh root tissues under study. A strong correlation was found between phenolic contents and antioxidant activities.

\section{REFERENCES}

[1] G. Padmaja, "Uses and Nutritional Data of Sweetpotato," In: G. Loebenstein and G. Thottappilly, Eds., The Sweetpotato, Springer, Dordrecht, 2009, pp. 189-234. doi:10.1007/978-1-4020-9475-0 11

[2] B. N. Ames, M. K. Shigenaga and T. M. Hagen, "Oxidants, Antioxidants, and the Degenerative Diseases of Aging," Proceedings of the National Academy of Sciences, Vol. 90, No. 17, 1993, pp. 7915-7922. doi:10.1073/pnas.90.17.7915

[3] J. W. Anderson, B. M. Johnstone and M. E. Cook-Newell, 
"Meta-Analysis of the Effects of Soy Protein Intake on Serum Lipids," New England Journal of Medicine, Vol. 333, No. 5, 1995, pp. 276-282. doi:10.1056/NEJM199508033330502

[4] J. A. Joseph, D. F. Bielinski and D. R. Fisher, "Blueberry Treatment Antagonizes C-2 Ceramide-Induced Stress Signaling in Muscarinic Receptor-Transfected COS-7 Cells," Journal of Agricultural and Food Chemistry, Vol. 58, No. 6, 2010, pp. 3380-3392. doi:10.1021/jf9039155

[5] R. Kurata, M. Adachi, O. Yamakawa and M. Yoshimoto, "Growth Suppression of Human Cancer Cells by Polyphenolics from Sweetpotato (Ipomoea batatas L.) Leaves," Journal of Agricultural and Food Chemistry, Vol. 55, No. 1, 2007, pp. 185-190. doi:10.1021/jf0620259

[6] A. Scalbert, C. Manach, C. Morand, C. Rémésy and L. Jiménez, "Dietary Polyphenols and the Prevention of Diseases," Critical Reviews in Food Science and Nutrition, Vol. 45, No. 4, 2005, pp. 287-306. doi:10.1080/1040869059096

[7] G. O. Rudkin and J. M. Nelson, "Chlorogenic Acid and Respiration of Sweet Potatoes," Journal of the American Chemical Society, Vol. 69, No. 6, 1947, pp. 1470-1475. doi:10.1021/ja01198a065

[8] I. Uritani and M. Miyano, "Derivatives of Caffeic Acid in Sweet Potato Attacked by Black Rot," Nature, Vol. 175, No. 4462, 1955, pp. 812-812. doi:10.1038/175812a0

[9] W. M. Walter, A. E. Purcell and G. K. McCollum, "Use of High-Pressure Liquid Chromatography for Analysis of Sweet Potato Phenolics," Journal of Agricultural and Food Chemistry, Vol. 27, No. 5, 1979, pp. 938-941. doi:10.1021/jf60225a031

[10] F. Hayase and H. Kato, "Antioxidative Components of Sweet Potatoes," Journal of Nutritional Science and Vitaminology (Tokyo), Vol. 30, No. 1, 1984, pp. 37-46. doi:doi:10.3177/jnsv.30.37

[11] K.-C. Son, R. F. Severson, M. E. Snook and S. J. Kays, "Root Carbohydrate, Organic Acids, and Phenolic Chemistry in Relation to Sweetpotato Weevil Resistance," HortScience, Vol. 26, No. 10, 1991, pp. 1305-1308.

[12] D. P. Thompson, "Chlorogenic Acid and Other Phenolic Compounds in Fourteen Sweet Potato Cultivars," Journal of Food Science, Vol. 46, No. 3, 1981, pp. 738-740. doi:10.1111/j.1365-2621.1981.tb15338.x

[13] M. Yoshimoto, R. Kurata-Azuma, M. Fujii, D.-X. Hou, K. Ikeda, T. Yoshidome and M. Osako, "Phenolic Composition and Radical Scavenging Activity of SweetpotatoDerived Shochu Distillery By-Products Treated with Koji," Bioscience, Biotechnology, and Biochemistry, Vol. 68, No. 12, 2004, pp. 2477-2483. doi:10.1271/bbb.68.2477

[14] J.-K. Jung, S.-U. Lee, N. Kozukue, C. E. Levin and M. Friedman, "Distribution of Phenolic Compounds and Antioxidative Activities in Parts of Sweet Potato (Ipomoea batata L.) Plants and in Home Processed Roots," Journal of Food Composition and Analysis, Vol. 24, No. 1, 2011, pp. 29-37. doi:10.1016/j.jfca.2010.03.025

[15] M. S. Padda and D. H. Picha, "Quantification of Phenolic Acids and Antioxidant Activity in Sweet Potato Geno- types," Scientia Horticulturae, Vol. 119, No. 1, 2008, pp. 17-20. doi:10.1016/j.scienta.2008.07.008

[16] M. Takenaka, K. Nanayama, S. Isobe and M. Murata, "Changes in Caffeic Acid Derivatives in Sweet Potato (Ipomoea batatas L.) during Cooking and Processing," Bioscience, Biotechnology, and Biochemistry, Vol. 70, No. 1, 2006, pp. 172-177. doi:10.1271/bbb.70.172

[17] V. D. Truong, R. F. McFeeters, R. T. Thompson, L. L. Dean and B. Shofran, "Phenolic Acid Content and Composition in Leaves and Roots of Common Commercial Sweetpotato (Ipomea batatas L.) Cultivars in the United States," Journal of Food Science, Vol. 72, No. 6, 2007, pp. C343-C349. doi:10.1111/j.1750-3841.2007.00415.x

[18] W. M. Walter and A. E. Purcell, "Evaluation of Several Methods for Analysis of Sweet Potato Phenolics," Journal of Agricultural and Food Chemistry, Vol. 27, No. 5, 1979, pp. 942-946. doi:10.1021/jf60225a030

[19] B. A. Cevallos-Casals and L. Cisneros-Zevallos, "Stoichiometric and Kinetic Studies of Phenolic Antioxidants from Andean Purple Corn and Red-Fleshed Sweetpotato," Journal of Agricultural and Food Chemistry, Vol. 51, No. 11, 2003, pp. 3313-3319. doi:10.1021/jf034109c

[20] T. Oki, M. Masuda, S. Furuta, Y. Nishiba, N. Terahara and I. Suda, "Involvement of Anthocyanins and Other Phenolic Compounds in Radical-Scavenging Activity of Purple-Fleshed Sweet Potato Cultivars," Journal of Food Science, Vol. 67, No. 5, 2002, pp. 1752-1756. doi:10.1111/j.1365-2621.2002.tb08718.x

[21] I. O. Rabah, D.-X. Hou, S.-I. Komine and M. Fujii, "Potential Chemopreventive Properties of Extract from Baked Sweet Potato (Ipomoea batatas Lam. Cv. Koganesengan)," Journal of Agricultural and Food Chemistry, Vol. 52, No. 23, 2004, pp. 7152-7157. doi:10.1021/jf049368w

[22] R. L. Prior, X. Wu and K. Schaich, "Standardized Methods for the Determination of Antioxidant Capacity and Phenolics in Foods and Dietary Supplements," Journal of Agricultural and Food Chemistry, Vol. 53, No. 10, 2005, pp. 4290-4302. doi:10.1021/jf0502698

[23] F. Rautenbach, M. Faber, S. Laurie and R. Laurie, "Antioxidant Capacity and Antioxidant Content in Roots of 4 Sweetpotato Varieties," Journal of Food Science, Vol. 75, No. 5, 2010, pp. C400-C405. doi:10.1111/j.1750-3841.2010.01631.x

[24] S. Furuta, I. Suda, Y. Nishiba and O. Yamakawa, "High tert-Butylperoxyl Radical Scavenging Activities of Sweet Potato Cultivars with Purple Flesh," Food Science and Technology International, Vol. 4, No. 1, 1998, pp. 33-35. doi:10.3136/fsti9596t9798.4.33

[25] Y.-C. Huang, Y.-H. Chang and Y.-Y. Shao, "Effects of Genotype and Treatment on the Antioxidant Activity of Sweet Potato in Taiwan," Food Chemistry, Vol. 98, No. 3, 2006, pp. 529-538. doi:10.1016/j.foodchem.2005.05.083

[26] M. S. Padda and D. H. Picha, "Phenolic Composition and Antioxidant Capacity of Different Heat-Processed Forms of Sweetpotato cv. 'Beauregard'," International Journal of Food Science \& Technology, Vol. 43, No. 8, 2008, pp. 1404-1409. doi:10.1111/j.1365-2621.2007.01663.x 
[27] T. Swain and W. E. Hillis, "The Phenolic Constituents of Prunus Domestica. I.-The Quantitative Analysis of Phenolic Constituents," Journal of the Science of Food and Agriculture, Vol. 10, No. 1, 1959, pp. 63-68.

doi: $10.1002 /$ jsfa. 2740100110

[28] M. S. Padda and D. H. Picha, "Methodology Optimization for Quantification of Total Phenolics and Individual Phenolic Acids in Sweetpotato (Ipomoea batatas L.) Roots," Journal of Food Science, Vol. 72, No. 7, 2007, pp. C412-C416. doi:10.1111/j.1750-3841.2007.00448.x

[29] C. F. R. Ferreira, P. Baptista, M. Vilas-Boas and L. Barros, "Free-Radical Scavenging Capacity and Reducing Power of Wild Edible Mushrooms from Northeast Portugal: Individual Cap and Stipe Activity," Food Chemistry, Vol. 100, No. 4, 2007, pp. 1511-1516. doi:10.1016/j.foodchem.2005.11.043

[30] W. Brand-Williams, M. E. Cuvelier and C. Berset, "Use of a Free Radical Method to Evaluate Antioxidant Activity," Lebensmittel-Wissenschaft and Technologie, Vol. 28,
No. 1, 1995, pp. 25-30.

doi:10.1016/S0023-6438(95)80008-5

[31] N. J. Miller and C. A. Rice-Evans, "Factors Influencing the Antioxidant Activity Determined by the ABTS ${ }^{\cdot+}$ Radical Cation Assay," Free Radical Research, Vol. 26, No. 3, 1997, pp. 195-199. doi: $10.3109 / 10715769709097799$

[32] L. E. Steed and V. D. Truong, "Anthocyanin Content, Antioxidant Activity, and Selected Physical Properties of Flowable Purple-Fleshed Sweetpotato Purees," Journal of Food Science, Vol. 73, No. 5, 2008, pp. S215-S221. doi:10.1111/j.1750-3841.2008.00774.X

[33] C. C. Teow, V. Truong, R. F. McFeeters, R. L. Thompson, K. V. Pecota and G. C. Yencho, "Antioxidant Activities, Phenolic and $\beta$-Carotene Contents of Sweet Potato Genotypes with Varying Flesh Colours," Food Chemistry, Vol. 103, No. 3, 2007, pp. 829-838. doi:10.1016/j.foodchem.2006.09.033 